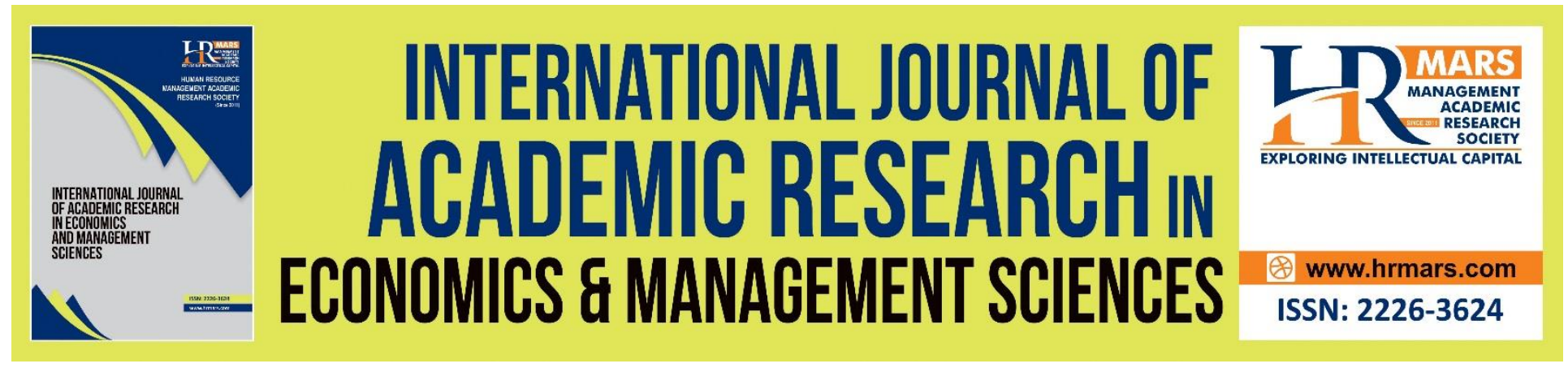

\title{
Factors Influencing Organizational Attractiveness among Millennial Job Seekers: A Study on Students in Malaysian Research Universities
}

Fariha Anjum Hira, Harcharanjit Singh, Nusrat Ahmed, Md. Moshiul Alam, Ahmad Imtiaj Nafis, Ahmad Ishtiak Nahid

To Link this Article: http://dx.doi.org/10.6007/IJAREMS/v10-i3/11165

DOI:10.6007/IJAREMS/v10-i3/11165

Received: 09 July 2021, Revised: 12 August 2021, Accepted: 06 September 2021

Published Online: 25 September 2021

In-Text Citation: (Hira et al., 2021)

To Cite this Article: Hira, F. A., Singh, H., Ahmed, N., Alam, M. M., Nafis, A. I., \& Nahid, A. I. (2021). Factors Influencing Organizational Attractiveness among Millennial Job Seekers: A Study on Students in Malaysian Research Universities. International Journal of Academic Research in Economics and Management and Sciences, 10(3), 383-400.

Copyright: (C) 2021 The Author(s)

Published by Human Resource Management Academic Research Society (www.hrmars.com)

This article is published under the Creative Commons Attribution (CC BY 4.0) license. Anyone may reproduce, distribute, translate and create derivative works of this article (for both commercial and non-commercial purposes), subject to full attribution to the original publication and authors. The full terms of this license may be seen at: http://creativecommons.org/licences/by/4.0/legalcode

Vol. 10, No. 3, 2021, Pg. 383 - 400

http://hrmars.com/index.php/pages/detail/IJAREMS

JOURNAL HOMEPAGE

Full Terms \& Conditions of access and use can be found at http://hrmars.com/index.php/pages/detail/publication-ethics 


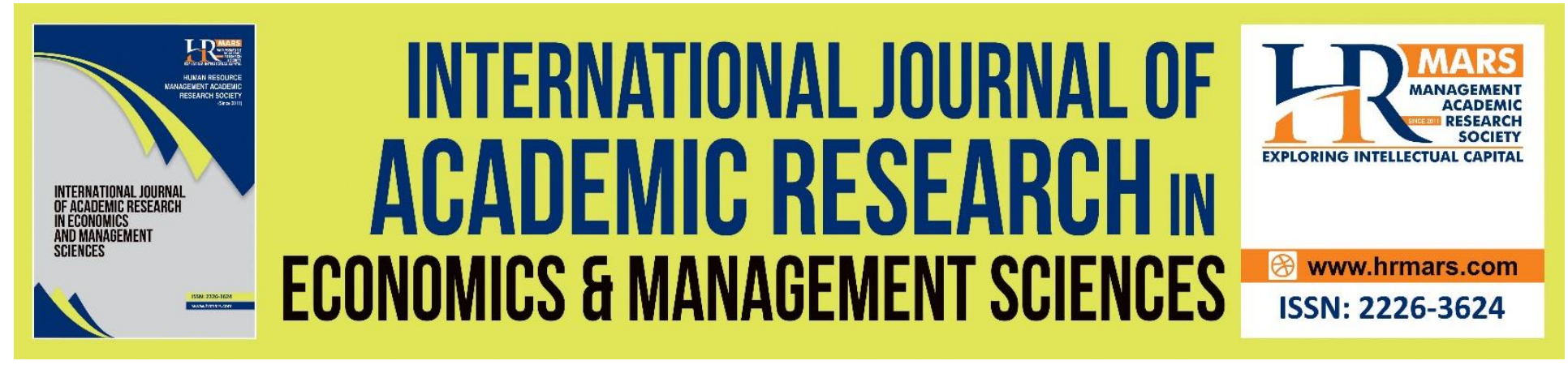

\title{
Factors Influencing Organizational Attractiveness among Millennial Job Seekers: A Study on Students in Malaysian Research Universities
}

\author{
Fariha Anjum Hira ${ }^{1}$, Harcharanjit Singh ${ }^{1}$, Nusrat Ahmed ${ }^{1}$, Md. \\ Moshiul Alam², Ahmad Imtiaj Nafis ${ }^{3}$, Ahmad Ishtiak Nahid ${ }^{4}$ \\ ${ }^{1}$ Azman Hashim International Business School, Universiti Teknologi Malaysia, Kuala Lumpur \\ 54100, Malaysia, ${ }^{2}$ Razak Faculty of Technology and Informatics, Universiti Teknologi Malaysia, \\ Kuala Lumpur 54100, Malaysia, ${ }^{3}$ Depertment of Computer Science and Engineering, Primeasia \\ University, Banani, Dhaka - 1213, Bangladesh, ${ }^{4}$ Department of Information and Communication \\ Technology, International Islamic University Malaysia, Kuala Lumpur, Malaysia address
}

\begin{abstract}
This study aims to empirically examine the influence of corporate social responsibility, perceived work environment, individual value, organizational reputation on organizational attractiveness among entry-level millennial job seekers of Malaysian research universities. The present study employs a quantitative method and commences a cross-sectional data collection via an online questionnaire where the research instruments were adopted from literature. A total of 400 (91\%) usable responses could be retained for further analysis. Using SPSS software for data analysis, descriptive statistics, factor analysis, and ANOVA findings were measured. This study bridges the literature gap on entry-level job-seeking millennials' perspectives in the Malaysian context. The study provides insight into organizational attractiveness amid the aftermath of the COVID-19 pandemic. Therefore, provisions understanding on employee's perception about the organization to managers and policymakers. The present study contributes theoretically to developing the conceptual model that can be further expanded and examined. Millennial jobseeking employee attraction in Malaysia is an under-explored research area that has been empirically tested in this study. The pandemic is likely to impact the employer branding concept from an employee's perspective. Therefore, the study finding provides preliminary insight to managers, policymakers, and government in proclaiming effective recruitment, employer branding, and talent acquisition policies accordingly.
\end{abstract}

Keywords: Employee Attraction, Human Resource Management, Malaysia, Millennials, Organizational Attractiveness 


\section{Introduction}

In this modern era, millennials are taking over a significant portion of the organizational workforce. Therefore, the global environment of the job market is gradually becoming more competitive. The "war for talent" and declining workforce is a dual burden for the organizations. Again, the fourth industrial revolution (IR 4.0) ushered in a paradigm change in the job market, requiring an independent and capable workforce to deal with global diversity. Organizations are in a time of transformation as the work market moves away from conventional hierarchies (Hira et al., 2021). Therefore, organizations have prioritized hiring millennials because of their adoptive and tech-savvy nature. Since 2019, the world has dealt with the COVID-19 pandemic, thus showing the global economic crisis. Global Financial Crisis (GFC) of 2007-08 shows that unemployment increased, especially among recent graduates aged 20 to 24 . According to human resource management (HRM), researchers agree that the pandemic would be a far greater threat to the labor market than the GFC (Shehzad, Xiaoxing \& Kazouz, 2020). They also predict that millennials' careers, especially those of recent graduates, are in trouble. To deal with the impending "career shock," an organization's strategy must be redesigned. The concept of "career shock" describes how this pandemic can alter career choices (Rudolph \& Zacher, 2020).

Since the GFC, millennials have been confronted with the absurd notion of global unemployment (Ismail \& Seng, 2016). The millennial generation accounts for half of the workforce worldwide (Calk \& Patrick, 2017). This generation will control $75 \%$ of the workforce by the next ten years. It is no surprise that millennials are expected to account for around $46 \%$ of the Malaysian workforce. Since the current K-economy and IR 4.0 age, institutions need techsavvy employees (Moore \& Khan, 2020). Malaysia faces a challenge in obtaining good role-playing functions from millennials in the workplace (Ismail \& Seng, 2016). Many managers have extensively accepted attracting millennials from several industries (Hendriks, 2016; Buzza, 2017). Organizations must attract millennials to the organizations under consideration in the Malaysian context because they must contribute to the "New Economic Model." Millennials' diversity and leadership qualities have prompted businesses to recognize their contribution to the Malaysian workforce, especially in the coming years (Hira et al., 2021). Increasing organizational attractiveness (OA) would help mitigate the millennial youth unemployment issue (Ismail \& Seng, 2016). Organizations need to search for ways to attract the best candidates for them. Therefore, organizations' lack of readiness to meet millennials' expectations will be a potential reason to fail to grab the best talent for the job market (Buzza, 2017). Again, youth unemployment in Malaysia has been an apprehension and sensitive community issue for decades (Nachiappan et al., 2018; Ramli et al., 2018). Approximately $24 \%$ of the graduates remained unemployed for at least a year after graduation (Arumugam et al., 2014).

The outcome of this study will allow the management to gain adequate human capital and decide who to become an "attractive employer" on the job market (Linden, 2015). Nevertheless, the OA of job applicants at the entry-level depends heavily on their perception as most of them have no prior work experience (Jones, Willness \& Madey, 2014). Reasons for the increased unemployment rate among millennials include millenniums in job quests selective based on work ethics, comfort in the organization's job, and policies. Millennials have particular organizational aspirations (Ibrahim \& Mahyuddin, 2017). Depending on these features, millennials develop organization fit beliefs (Appel-Meulenbroek et al., 2019; Ramli et al., 2018). Accordingly, OA's definition has shifted to include soft factors like organizational perceptions of 
the workplace atmosphere and social benefits. Also, researchers are concerned that the job market for entry-level millennial job seekers (MJS) who are between fresh graduates will get much worse because of imminent COVIE-19 (Hira et al., 2021).

Moreover, due to the millennial's inherent nature, it is difficult for organizations to pinpoint what they want the most. At the same time, attracting millennials towards organizations is needed for both the millennials and the organization. Therefore, unearthing the factors that attract millennials to organizations is essential but lacking in the literature. As such, this study aims to close this gap and provide insights for employers about how to entice MJS. Many studies are available on millennials, but very few studies on millennial fresh graduates' OA. Research previously examined millennials' long-specific employability, all of which had been done with current workers in-self-employees in mind (Kinash, 2016). Entry-level MJS search job depending on perception; therefore, substantial research is needed focusing on this group, but knowledge on this phenomenon is inattentive. In contrast to a plethora of studies on OA, a nascent number of research focused on the influences of MJS's perception towards the organization (AppelMeulenbroek et al., 2019; Catano \& Morrow, 2016). Moreover, OA-related studies predominantly focus on employee retention than attraction. Hardly any consideration has been devoted to investigating millennial entry-level graduate job seekers' attitudes to the organization (Youn, Lee \& Lee, 2018). However, to the researcher's best knowledge, there is no empirical finding available in Malaysia on research university students regarding OA while preparing to look for a job (Ismail \& Seng, 2016).

The purpose of this study is to examine the impact of four influential factors, namely, corporate social responsibility, work environment, individual value, and organizational reputation, on organizational attractiveness among millennial job seekers. As a result, the purpose of this research is to fill that void. The research seeks the answer to the question of dose corporate social responsibility, perceived work environment, individual value, organizational reputation impacts the organization's attractiveness? Consequently, the research objective is to examine the influence of corporate social responsibility, perceived work environment, individual value, and organizational reputation on MJS's organization attractiveness. With the help of hypotheses, this research intended to address the research gaps. Also, it provides recommendations for future research. Investigating the relationship between the variables has theoretical support from social identity theory and signaling theory.

\section{Literature Review}

This section comprises of underpinning theory and conceptual model development

\section{Signaling Theory}

The signaling theory has been developed on the basics of the job market signaling concept. According to the Theory, among the two parties, one of them will be involved in observable mechanisms (millennial job-seeking youths) to another party (employer) exhibit its unobservable features (For example, efficiency). HRM scholars used this theory to explain why conducting CSR activities with potential benefits for the organization is a component of OA (Su et al., 2016). This study explains CSR practice as a quality signal for the MJS that reveals additional information about the organization (Spence, 1973). The ST is also applicable to understanding how an organizations' CSR work environment could influence OA. Therefore, MJS interprets the 
organization's work environment and CSR work environment policy as a signal before developing a sense of value fit.

\section{Social Identity Theory}

Social Identity Theory (SIT) was developed based on belonging. This theory describes how individuals look for self-identity about social groups depending on belonging and categorization of "in-group" and "out-group" protects. Organizational values enhance an individual's social identity. Therefore, job seekers look for self and organizational value-fit factors (Chapola, 2016). SIT has been used in different previous studies as a theoretical mechanism connecting InV and ORn with OA (Slade, Ribando \& Fortner, 2016). ORn is a vital component of OA (Xie et al., 2015). A positive ORn is very appealing to MJS, and a negative reputation discourages being attracted toward that organization as millennials are conscious about self-enhancing employment settings (Chapola, 2016). Similarly, all MJS will not feel attracted to an organization based on the workplace environment's information and CSR policies (Gully et al., 2013). Job seekers holding a conservative way of thinking and resisting change are likely to oppose social welfare based on self-betterment and values. Furthermore, a negative ORn can also create a withdrawal tendency among job seekers as their value will not be the same as the organization used to carry. They tend not to be influenced by that organization due to a lack of self-belonging factor (Jones et al., 2014). Thus, the conceptual framework in Figure 1 has been adopted from Hira et al (2021), which was developed based on these two theories to test empirically.

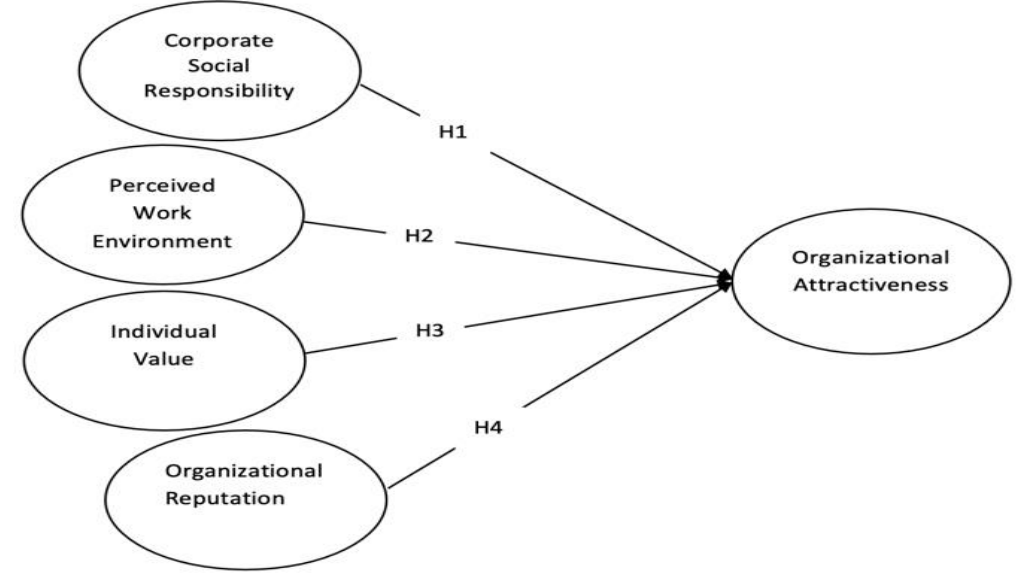

Figure $1 . \quad$ Conceptual framework

\section{Hypothesis Development}

Corporate Social Responsibility

Corporate social responsibility (CSR) means the configuration of social responsibility, social responsiveness mechanisms, strategies, services, and measurable results concerning a company's social ties (Catano \& Morrow, 2016). CSR plays a crucial role in increasing OA. Millennials who are willing to contribute to social well-being find an organization more attractive that mentions their CSR policy's details, activity in recruitment advertisement (Parks-Leduc, Feldman \& Bardi, 2015). Job seekers perceive that organizations with favorable CSR policies "Care for" their employees. Therefore, attractive CSR activities could influence more potential job seekers (Martin \& Ottemann, 2016). According to Chapola (2016), "Employees, and presumably 
job applicants, prefer to work in socially responsible organizations and exhibit a strong commitment to organizations with positive CSR policies." Jones et al. (2014) revealed that in a job fair, an organization that advertised itself as being committed to society's betterment and pro-environmental activities could grab more job seekers than other organizations. Based on the findings from several previous studies, it can be concluded that job seekers are more willing to work with such organizations with firm CSR policies, values, and activities. Several studies found a direct, significant, and positive relationship between CSR and OA (Adetunji \& Ogbonna, 2013; Chapola, 2016; Jones et al., 2014; Parks-Leduc, Feldman \& Bardi, 2015; Story et al., 2016).

On the other hand, Appel (2014) and Gully (2013) found a positive yet insignificant relationship between CSR and OA. Based on the literature, there is inconsistency in the findings regarding CSR and OA. Due to finding inconsistency in prior studies, Martin and Ottemann (2016) suggested testing the relationship between CSR and OA. Thus, the following hypothesis was developed.

H1: $\quad$ CSR has significant positive influences on OA

\section{Perceived Work Environment}

Millennials' OA deepens on several components of the Perceived Work Environment (PWE). They expect recognition, respect from the workplace, and satisfactory payment for the skill sets that they carry and use in the organization (Caraher, 2015; Taylor, 2014). Organizations that can provide millennials with a very casual working environment feel attracted to join them (Caraher,2015). Organizations capable of creating a positive perception about the organization's work environment are more attractive to job-seeking millennials (Taylor, 2014). Catano and Morrow (2016) also contended that a healthy or positive vibe of the work environment could improve millennial job seekers' ORn. MJS has an additional concern regarding an organization's work environment (Caraher, 2015). They look for information to create a perception of the work environment while seeking a job. Millennials care for a pleasant place to work in an organization that provides a healthy workplace environment (Taylor, 2014). Positive perceptions regarding the workplace environment immediately and directly impact MJMS(Catano \& Morrow, 2016). Previous studies also mentioned that workplace that is flexible and customizable are likely to attract job seekers. Hendriks (2016) used a spreadsheet to conduct analysis using their own and most common concept regarding work environment and found positive relation with OA. Yi et al. (2013) inspected the influence of physical workplace environments and found a positive relationship between them in Scotland's call-center industry context. Based on the discussion and suggestions, the following hypothesis was developed.

\section{H2: $\quad$ PWE has significant positive influences on OA}

\section{Individual Value}

Individual values (InV) represent people's emotional and intellectual principles that guide people's liv, es including choice. In other words, InVs serve as the foundation for an individual's perspective. As such, they are necessary components of an individual's conduct at the outset of a decision-making process. Additionally, these are the aspects that influence and increase our understanding of human behavior (Kaygin, gulluce, 2013). InV decides person-organization fit 
perception, and positive perception towards the organization pushes the job seeker to feel attracted (Catano \& Morrow, 2016; Jones et al., 2014). Catano and Morrow (2016) mentioned that their study finding illustrated an influential positive impact on job-seeking millennial students as the youths of generation focus "on individual needs rather than on organizational ones." Story et al. (2016) conducted the only experimental study on the InV fit of job seekers based on their perception and found that job seeker's esteem and expected treatment positively affects OA. Parks-Leduc et al. (2015) contended that InV insists job seekers look for the comfort zone to work with similar others. Therefore, MJS seeks the best match of organizational value with their value as an individual. Therefore, MJS aims to have a value fit with the organization while looking for a job (Catano \& Morrow, 2016). Many researchers found a positive and significant relationship between InV and OA (Catano \& Morrow, 2016; Derous \& Wille, 2017; Parks-Leduc et al., 2015; Story et al., 2016). Kaygin and Gulluce (2013) found a moderate positive significant correlation between InV and OA. However, Gully (2013) and Jones et al. (2014) found no relationship in few constructs of $\ln V$ to $O A$. There is inconsistency in the findings concerning InV and OA. Hence, Catano and Morrow (2016) suggested more research on the relationship between InV and OA. Based on the discussion and suggestions, the following hypothesis was developed.

\section{H3: $\quad$ InV has significant positive influences on OA}

\section{Organizational Reputation}

Organizational reputation (ORn) "refers to people's global impressions of an organization and is defined as people losing structures of knowledge and beliefs about an organization. According to Yi et al. (2013), OA is a prerequisite that appeals to millennial job seekers' attention to the emphasis on ORn. Millennials consider their perception of the company as a tool of OA that links with its reputation (Jones et al., 2014). Thus, ORn is the essential measure of OA among MJS as they search for reputed organizations (Jones et al., 2014). Therefore, ORn significantly affects OA. Hendriks (2016) found that ORn has significant OA and plays a crucial role in the recruitment process (Hendriks, 2016; Cho, 2015). Nevertheless, more research is needed between ORn and OA (Xie, Bagozzi, \& Meland, 2015). The organization's positive reputation is better in attracting job seekers. Previous studies found a significant relationship between ORn and OA (Jones et al., 2014; Yuksel, 2015). Based on the discussion and suggestions, the following hypothesis was developed.

H4: ORn has significant positive influences on OA

\section{Methodology}

\section{Research Design}

The positivism paradigm approach was implemented in this descriptive, single cross-sectional study.

\section{Data Collection and Analysis}

This study adopted a non-probability or convenience sampling technique. The sample was collected from five public research universities in Malaysia: Universiti Malaya, Universiti Putra 
Malaysia, Universiti Kebangsaan Malaysia, Universiti Teknologi Malaysia, and Universiti Sains Malaysia (Ban \& Kee, 2018). According to the Krejcie \& Morgan (1970) sample size table, as the actual population is more than 1000000 , this study required 384 sample sizes to cover the people. Questionnaires were distributed among the five research universities students from January to February 2021 via email and WhatsApp groups, where data was received at different times. A five-point Likert scale from 1, strongly disagrees to 5 , strongly agree was utilized. The instruments were adopted from literature, as mentioned in Appendix. Statistical Package for the Social Sciences (SPSS) software version 25 was used to measure the respondents' coefficient alpha value of the questionnaires completed.

\section{Non-Response Bias}

When the respondents of the sample population do not respond to the distributed questionnaires, then non-responsive bias occurs. The researcher used only one method to distribute the questionnaires for data collection of this study: online distribution.

\section{Data Analysis and Results}

\section{Descriptive Analysis}

As per frequency distribution, $48 \%$ of the questionnaires were answered by male respondent's where the female participation rate was $52 \%$. Therefore, it can be considered that the questionnaire distribution based on gender was quite equal. The ethnicity of Malay, Indian, Chinese, Others were 53.0\%, 14.8\%, 18.3\%, and 14.0\%, respectively. Frequency analysis shows that most respondents are between 23-26 years old, and the percentage accounts for $43.5 \%$ of the total participants. Followed by age group is 31-34 (24.5\%) and 19-22 (21\%). Minority for participants from age group $27-30,35-38$ years old and the percentage is $2.3 \%, 8.8 \%$ respectively. $52.3 \%$ respondents are degree students followed by $21.3 \%$ (85) Master, $17.8 \%$ (71) Diploma holder, $7.8 \%$ (31) of PhD students. Only 1\% (4) of the students belong to other educational qualification groups.

\section{Reliability}

A reliability check indicates a measuring tool's inner consistency. The Cronbach's coefficient alpha value for the dependent variable, the OA, was 0.628 , and Cronbach's coefficient alpha values for IVs (independent variables) were 0.69 on average. In addition, for CSR, PWE, InV, ORn Cronbach's coefficient alpha values were $0.720,0.686,0.719,0.686$, respectively (refer to Table 1 ). A total of four (4) items has been removed from OA, CSR, PWE, ORn. 1 item was deleted from each of these variables. No items were deleted from InV. 
INTERNATIONAL JOURNAL OF ACADEMIC RESEARCH ECONOMICS AND MANAGEMENT SCIENCES

Vol. 10 , No. 3, 2020, E-ISSN: 2226-3624 ㄷ 2020 HRMARS

Table 1. Reliability Results

\begin{tabular}{lccc}
\hline Variables & $\begin{array}{l}\text { Item } \\
\mathrm{s}\end{array}$ & $\begin{array}{c}\text { Number of } \\
\text { Items } \\
\text { deleted }\end{array}$ & $\begin{array}{c}\text { Cronbach's } \\
\text { Coefficient Alpha }\end{array}$ \\
\hline $\begin{array}{l}\text { Corporate Social } \\
\text { Responsibility }\end{array}$ & 7 & 1 & 0.720 \\
$\begin{array}{l}\text { Perceived Work } \\
\text { Environment }\end{array}$ & 4 & 1 & 0.686 \\
$\begin{array}{l}\text { Individual Values } \\
\text { Organizational Reputation } \\
\text { Organizational }\end{array}$ & 8 & None & 0.719 \\
Attractiveness & 6 & 1 & 0.686 \\
\hline & & 1 & 0.628
\end{tabular}

Pearson Correlation Coefficient Analysis

Table 2 demonstrates a significant relationship between the dependent variable, OA, and three independent variables: CSR, InV, and ORn.

Table 2. Pearson Correlation Coefficient between variables

\begin{tabular}{llllll}
\hline & \multicolumn{1}{c}{ OA } & CSR & PWE & InV & ORn \\
\hline OA & 1 & & & & \\
CSR & $0.604^{* *}$ & 1 & & & \\
PWE & $0.263^{* *}$ & $0.278^{* *}$ & 1 & & \\
InV & $0.494^{* *}$ & $0.567^{* *}$ & $0.263^{* *}$ & 1 & \\
ORn & $0.433^{* *}$ & $0.416^{* *}$ & $0.409^{* *}$ & $0.438^{* *}$ & 1 \\
\hline
\end{tabular}

** Correlation is significant at the 0.01 level (2-tailed)

Independence of Residuals

Residuals can be normally distributed if the value of Durbin Watson's statistical shows closeness to 1.0. Table 3 demonstrates that the Durbin-Watson value for this research is 1.620 , which justifies the normal distribution.

Table 3. Model Summary of Multiple Regression Model

\begin{tabular}{|c|c|c|c|c|}
\hline Model R & R Square & $\begin{array}{l}\text { Adjusted R } \\
\text { Square }\end{array}$ & $\begin{array}{l}\text { Std, Error of the } \\
\text { Estimate }\end{array}$ & $\begin{array}{l}\text { Durbin- } \\
\text { Watson }\end{array}$ \\
\hline $\begin{array}{l}.651 \\
a\end{array}$ & .424 & .418 & .34382 & 1.620 \\
\hline
\end{tabular}

Predictors: (Constant), ORn, PWE, CSR, InV

Dependent Variable: OA

ANOVA is another multiple regression analysis to test the statistical significance primarily as designated by Table 4 . The outcome demonstrates that $P<0.005)$. The values indicate a 
INTERNATIONAL JOURNAL OF ACADEMIC RESEARCH ECONOMICS AND MANAGEMENT SCIENCES

Vol. 10 , No. 3, 2020, E-ISSN: 2226-3624 ㄷ 2020 HRMARS

significant relationship between the DV (dependent variable) and the amalgamation of IVs (independent variables) advocates that a coincidental correlation occurred among the IVs.

Table 4. Multiple Regression Model - ANOVA

\begin{tabular}{lllllll}
\hline & Model & $\begin{array}{l}\text { Sum of } \\
\text { Squares }\end{array}$ & df & $\begin{array}{l}\text { Mean } \\
\text { Square }\end{array}$ & $F$ & Sig, (P) \\
\hline 1 & Regression & 34.343 & 4 & 8.586 & 72.630 & $.000 \mathrm{~b}$ \\
& Residual & 46.694 & 395 & .118 & & \\
& Total & 81.037 & 395 & & & \\
\hline
\end{tabular}

a Dependent Variable: OA

b Predictors: (Constant), ORn, PWE, CSR, InV

The Standardized coefficient beta and the significant value is an indication to test the hypothesis established in this research. The beta from Table 5 reflects the influence of each independent variable against the dependent variable. The beta value allows for the strength comparison among the dependent variable.

Table 5. Multiple Regression Model - Coefficient

\begin{tabular}{|c|c|c|c|c|c|c|}
\hline & & $\begin{array}{l}\text { Unst } \\
\text { Coef }\end{array}$ & $\begin{array}{l}\text { dardized } \\
\text { ent }\end{array}$ & $\begin{array}{l}\text { Standardized } \\
\text { Coefficient }\end{array}$ & & \\
\hline & Model & B & $\begin{array}{l}\text { Std. } \\
\text { Error }\end{array}$ & Beta & $\mathrm{t}$ & Sig. \\
\hline 1 & (Constant) & .966 & .218 & & 4.428 & .000 \\
\hline & $\begin{array}{l}\text { Corporate } \\
\text { Social } \\
\text { Responsibility }\end{array}$ & .426 & .048 & .429 & 8.959 & .000 \\
\hline & $\begin{array}{l}\text { Perceived } \\
\text { Work } \\
\text { Environment }\end{array}$ & .029 & .040 & .031 & .725 & .469 \\
\hline & $\begin{array}{l}\text { Individual } \\
\text { Value }\end{array}$ & .181 & .051 & .171 & 3.537 & .000 \\
\hline & $\begin{array}{l}\text { Organizational } \\
\text { Reputation }\end{array}$ & .132 & .036 & .168 & 3.648 & .000 \\
\hline
\end{tabular}

\section{a. Dependent Variable: OA}

Lastly, collinearity statistic outcomes were utilized to determine the existence of multicollinearity in this study. Predominantly, the Variance Influence Factor (VIF) guides the determination process of multicollinearity among the predictors. VIF value higher than 5.0 represents the presence of high multicollinearity. High multicollinearity issues may interrupt the result interpretation (Zikmund et al., 2013). The resulting outcome of tolerance mentioned in Table 6 clarifies no collinearity issue as all the values are more significant than 0.2 . 
Table 6. Coefficient Multiple Regression Model - Collinearity Statistic

\begin{tabular}{llll}
\hline \multicolumn{3}{c}{ Collinearity Statistic } & \\
& Model & Tolerance & VIF \\
\hline 1 & $\begin{array}{l}\text { (Constant) } \\
\text { Corporate Social } \\
\text { Responsibility } \\
\text { Perceived Work }\end{array}$ & .638 & 1.568 \\
& & \\
Environment & .817 & 1.225 \\
Individual Value & & \\
& Organizational Reputation & .691 & 1.594 \\
\hline
\end{tabular}

Dependent Variable: OA

Table 7. Summary of Research Hypothesis Testing Result

\begin{tabular}{lll}
\hline Hypothesis & Hypothesis & Decision \\
\hline Hypothesis 1 & CSR has significant positive influences on OA & Supported \\
Hypothesis 2 & PWE has significant positive influences on & Unsupported \\
& OA &
\end{tabular}

Hypothesis 3 InV has significant positive influences on OA Supported

Hypothesis 4 ORn has significant positive influences on Supported

$\mathrm{OA}$

The finding of the $\mathrm{H} 1$ reviled that corporate social responsibility has a positive and significant influence on organizational attractiveness. This finding has similarities with some previous research findings (Adetunji \& Ogbonna, 2013; Feldman \& Bardi, 2015; Jones et al., 2014; Waples \& Brachle, 2020). The inclusive organizational culture of CSR and policy development regarding such activities can be advertised while looking for new recruitment. A significant relationship between CSR also indicates that millennial job seekers want to be a part of such an organization concerned about society. CSR strategy can complement the management system of several organizations from different industries with their willingness to remain successful. The hypothesis, $\mathrm{H} 2$ was not supported, which has similarities with the past study findings of Taylor (2014). Depending on the data collected from the respondents, job seekers replied that they were not concerned about the work environment. However, this current research finding is the opposite of Catano and Morrow (2016). They mentioned that policy regarding healthy or positive vibe of work environment could improve organizational attractiveness among MJS. This research finding says that although perceived work environment positively influences job-seeking millennials in terms of increased organizational attractiveness in the Malaysian context, insignificant. Perception of the work environment, depending on several factors, can be different such as age, gender, generation, level of education, or work experience. Therefore, this research finding can be justified based on the statement of Everett (2011). H3 has been supported and has similarities with previous studies (Catano \& Morrow, 2016; Derous \& Wille, 2017; Story et al., 2016). Job seekers seek value-fit with the organization while looking for a job. The research outcome contradicts the finding of Gully (2013), as the scholar argued that millennial job seekers who are self-centered value self-enhancement. Therefore, MJS may have different points of view regarding individual and organizational value fit that may show no relationship with 
organizational attractiveness. According to Jones et al. (2014), progressive policies of an organization may create a negative value perception among the self-centered group of millennials. Thus, MJS can be less attracted to organizations with progressive policies and practices Jones et al. (2014). H4 has been supported and in line with the past study finding of Jones et al. (2014) and Yuksel (2015). MJS search for reputed organizations while looking for a job. Working for organizations with a positive organizational reputation shapes appearance of the organization as the organization encourages the self-esteem of job seekers that upsurges the organizational attractiveness to potential job seekers (Chapola, 2016).

\section{Contributions}

Theoretical Contribution

This research supports the emerging tendency of millennial job seekers' perceptions by suggesting a research framework to justify the importance of their perception towards an organization and the factors that can trigger their perception positively improving $\mathrm{OA}$. This research has a strong impact in contributing to the usage of the Social Identity Theory (Tajfel \& Turner, 1979) and Signaling Theory (Spence, 1973). Theoretical background was developed based on Signalling Theory and Social Identity Theory. The theories provide analytical support to the influential factors on OA, mostly explaining CSR, PWE, InV, ORn, perceived ease of job seekers perception, and predictor for OA. This study can fill the gap between existing studies on the same research problem and the lack of research in the Malaysian context. Furthermore, this is one of the first studies conducted considering Malaysia's millennial job-seeking student's perception of OA.

\section{Managerial Contribution}

This study found the most significant influencing factors towards OA among MJS. Therefore, research can significantly assist managers, specifically HR managers of several organizations, in recognizing the most influential factors to create an image as an attractive employer. Also, this study provides managers with a meaningful insight interim of understanding the requirements from a different perspective of job-seeking millennials expectations from an organization. Furthermore, this study can guide advisors, especially for HR managers in any organization from any industry in Malaysia, as HRM needs to have a clear picture regarding the expectation of millennials to attract the best talent from the potential job seekers. HR is the core competency of an organization to stay competitive in the relevant industry. Therefore, the finding of this study will assist managers in planning competitive HR practices (Yi et al., 2013).

Policy Maker

A country's unemployment rate depends on government policies (Ramli et al., 2018), and employee attraction depends on the organizational recruitment policy. Therefore, from the policy makers' point of view, the outcomes of this research articulate strategies in prevailing the OA by considering the individuals' perception, need, and expectation from an organization not only for the organizations but also for a nation. Policies and a set of producers can also be articulated to enhance the OA among millennials. This study has a significant contribution regarding recruitment policymaking and redesigning. Organizations to have progressive benefits for potential job seekers in terms of physiological perception of belonging. Therefore, 
organizational or employer branding strategy and policy should be in place. The finding can guide policymakers to develop lucrative employer branding strategies and policies (Kaifi et al.,2014).

Despite increased demand for the job market, millennials are not participating as expected (Ismail \& Seng, 2016). Influential factors increase organizational attractiveness, easing unemployment problems as previous research suggested (Linden, 2015). Therefore, the national level decision-makers (ministry) can take theoretical support from this research to develop or redesign a policy that will insist millennials venture onto the job market. Research findings can assist the management of an organization with strategic planning and policy development capable of constructing a fairer and substantial work environment for Millennial youth employees (Jehn \& Scott, 2015). Moreover, a well-defined strategy can be designed for better talent management and attraction.

Millennials have an organization switching tendency. Therefore, developing policies and bringing that into practice will trigger MJS's value as an individual to be a part of the organization (Appel, 2014). Policymakers can easily formulate policies to develop authentic employer image development (Kaifi et al.,2014). Organizations can be consequently more effective while looking for the best talents. Millennials' initial attraction to an organization is authenticated on their perception of its CSR activities, reputation, and how much they are committed to serving society (Chapola, 2016). As CSR is opted by modern organizations, this study can assist organizations in upbraiding a new CSR tool and better insight's view. Organizations should realize and redesign employee attraction policy and procedures to attract the best talents (Appel-Meulenbroek et al., 2019). Although organizations are being more aware of their image in terms of providing a pleasant working environment according to millennials' expectations, the initiative taken by the organizations is not being appreciated by the MJS as expected (Appel, 2014).

\section{Limitation of Study and Future Research Direction}

Due to time constrain, the research was only limited to the research universities of Malaysia. The scope was limited only to university students. This study did not consider the respondent's work experience. Another limitation can be the quality of the data collected, as the study evaluated only 400 responses for analysis. Data accuracy cannot be guaranteed as there is no alternative to determine that the respondents' response is the true reflection of their perception of OA. This research focused on a limited area of OA, overlooking the other potential factor that may influence OA. The nature of the study and the culture of intuition has their characteristics. Due to those factors, the research results are only relevant for Malaysian millennial job-seeking students. OA studies mostly retain employees, but the research on MJS perception and employee attraction while hiring new employees is minimal. The researchers being millennial students at a research university, conducted this research that may induce bias. However, all precautions were taken to keep the research as objective as possible.

There is a substantial-high scope for further research to be carried out in the future that may increase the engagement between job seekers and employers. The advanced study can take other specializations of study under consideration, such as medical, engineering, MBA students, to develop a clear understanding of whether the influencing factors have a similar impact on them or not. This research population belongs to Malaysia only. Therefore, further research can consider other countries for research. This research considered only students, not any specific 
industry. Thus, the research scope may expand more towards industry-specific. For example, millennials are those who are working in the financial service or healthcare industry.

Moreover, other influencing factors can be included in the framework, or the relationship between ORn and CSR can be examined. Further understanding is required for the organizations in this rea with the changing over generations in the workforce to support effective HRM practice. Future research can examine the factors that have similar or dissembler influences on OA based on gender. Social Identity Theory, Signalling theory can be extended in future research regarding the same disciplinary studies as both theories have been examined concerning OA with the support of previous studies.

\section{Conclusion}

Traditional, the traditional concept of the responsibility of business has been changed. Business organizations and stakeholders are adopting the "3P" business model concept. The idea encourages social responsibility under consideration, known as "triple bottom line," or TBL. The "three Ps" represent "people, planet and profit" (Hussain, Rigoni \& Orij, 2018). Therefore, CSR is part and parcel of every organization in this era. Job seekers look for person-organization fill based on their values and individuals. Therefore, the progressive organizational policy can be attractive to millennial job seekers, and consequently, they will be willing to be a part of that organization. People want to carry the pride of being part of a well-reputed organization. A positive organizational reputation attracts job seekers positively. This research successfully established the positive and significant relationship among these IVs with ORn. Five (5) Research University students of Malaysia were chosen as targeted respondents for this study to test hypothesized relationships among variables. The present research is one of the first pieces of research conducted on job-seeking millennials' perception of the Malaysian context. This study can be very assistive for the Malaysian government and non-movement or private sector organizations for policymaking. It is expected that a developed or redesigned policy, depending on this research outcome, will ease the unemployment issue from the job seeker's perspective. On the other hand, it will eliminate employee shortage, an attraction issue for organization or employer perspective.

\section{References}

Adetunji, O. J., \& Ogbonna, I. G. (2013). Corporate social responsibility as a recruitment strategy by organizations. International Review of Management and Business Research, 2(2), 313.

Appel, L. (2014). CSR as a factor in the war for talents (Master's thesis, University of Twente). Appel - Meulenbroek, H. A. J. A., Vosters, S. M. C., Kemperman, A. D. A. M., \& Arentze, T. A. (Accepted/In press). Workplace needs and their support; are millennials different from other generations?. 1-14. Paper presented at Twenty fifth annual Pacific Rim Real Estate Society conference (PRRES 2019), Melbourne, Australia.

Arumugam, N., Thayalan, X., Dass, L. C., \& Maniam, M. (2014). Unemployment among graduate nurses in Malaysia: a case study. Asian Social Science,10(9), 227.

Ban, D. T. K., \& Kee, D. M. H. (2018). How does Work Engagement Affect Psychosocial Safety Climate and Burnout? The Case of the Malaysian Research Universities. Asia Proceedings of Social Sciences, 2(4), 60-64. 
Buzza, J. S. (2017). Are You Living to Work or Working to Live? What Millennials Want in the Workplace. Journal of Human Resources, 5(2), 15-20.

Calk, R., \& Patrick, A. (2017). Millennials through the looking glass: Workplace motivating factors. The Journal of Business Inquiry, 16(2), 131-139.

Caraher, L. (2015). Millennials and management. The essential guide to making it work at work. Brookline: Bibliomotion.

Catano, V. M., \& Morrow Hines, H. (2016). The influence of corporate social responsibility, psychologically healthy workplaces, and individual values in attracting millennial job applicants. Canadian Journal of Behavioural Science/Revue canadienne des sciences du comportement, 48(2), 142.

Cho, J. (2015). Employer Branding through CEO's Message: Individual valueestigation of CEO's Social Media Use's Effects on Organizational Images and Job Pursuit Intentions among Millennials. 홍보학연구, 19(2), 74- 95.

Chapola, J. (2016). An empirical analysis of job seekers' perception of corporate social performance as a measure of organisational attractiveness (Doctoral dissertation).

Derous, E., \& Wille, L. (2017). Organizational attraction. In The SAGE encyclopedia of industrial and organizational psychology (Vol. 3, pp. 1060-1064).

Everett, A. (2011). Benefits and Challenges of Fun in the Workplace. Library Leadership \& Management, 25(1).

Gully, S. M., Phillips, J. M., Castellano, W. G., Han, K., \& Kim, A. (2013). A mediated moderation model of recruiting socially and environmentally responsible job applicants. Personnel Psychology, 66(4), 935-973.

Hendriks, M. (2016). Organizational reputation, organizational attractiveness and employer branding: clarifying the concepts(Master's thesis, University of Twente).

Hira, F. A., Singh, H., Alam, M. M., \& Ishtiak, A. (2021). A Conceptual Framework for Organizational Attractiveness among Malaysian Millennial Jobseekers Aimed at the Aftermath of COVID-19. International Journal of Academic Research in Economics and Management Sciences, 10(1), 20-33. DOI: 10.6007/IJAREMS/v10-i1/8871

Hussain, N., Rigoni, U., \& Orij, R. P. (2018). Corporate governance and sustainability performance: Analysis of triple bottom line performance. Journal of Business Ethics, 149(2), 411-432.

Ibrahim, D. H. M., \& Mahyuddin, M. Z. (2017). Youth Unemployment in Malaysia: Developments and Policy Considerations. Outlook and Policy, Annual Report.

Ismail, N. H., \& Seng, L. C. (2016). The bold initiatives of the Ministry of Higher Education Malaysia in preparing Millennial learners to enter the workforce. International Journal of Advanced Engineering and Management Research, 1(3), 241-255.

Jehn, K. A., \& Scott, E. D. (2015). Lies in the sky: Effects of employee dishonesty on organizational reputation in the airline industry. Business and Society Review, 120(1), 115-136

Jones, D. A., Willness, C. R., \& Madey, S. (2014). Why are job seekers attracted by corporate social performance? Experimental and field tests of three signal-based mechanisms. Academy of Management Journal, 57(2), 383-404.

Jones, D. A., Willness, C. R., \& Heller, K. W. (2016). Illuminating the signals job seekers receive from an employer's community individual valueolvement and environmental 
sustainability practices: Insights into why most job seekers are attracted, others are indifferent, and a few are repelled. Frontiers in psychology, 7, 426.

Kaifi, B. A., Khanfar, N. M., Noor, A. O., \& Poluka, L. (2014). International business students' understanding, perception, and commitment to corporate social responsibility: A study based upon gender, generational affiliation and culture. Business and Management Research, 3(3), 34-42.

Kaygin, E., \& Gulluce, A. C. (2013). The relationship between career choice and individual values: A case study of a Turkish University. International journal of humanities and social science, 3(3), 119-134.

Krejcie, R. V., \& Morgan, D. W. (1970). Determining sample size for research activities. Educational and psychological measurement, 30(3), 607-610.

Linden, S. J. (2015). Job expectations of employees in the millennial generation.

Moore, K., \& Khan, M. H. (2020). Signalling organizational commitment to employability through job advertisements: the communication of HRD practices to young inexperienced job seekers. Human Resource Development International, 23(1), 25-45.

Martin, T. N., \& Ottemann, R. (2016). Generational workforce demographic trends and total organizational rewards which might attract and retain different generational employees. Journal of Behavioral and Applied Management, 16(2), 1160.

Parks-Leduc, L., Feldman, G., \& Bardi, A. (2015). Personality traits and personal values: A metaanalysis. Personality and Social Psychology Review, 19(1), 3-29.

Ramli, S. F., Firdaus, M., Uzair, H., Khairi, M., \& Zharif, A. (2018). Prediction of the unemployment rate in malaysia. International Journal, 1(4), 38- 44.

Rudolph, C. W., \& Zacher, H. (2020). COVID-19 and careers: On the futility of generational explanations. Journal of Vocational Behavior, 103433.doi:10.1016/j.jvb.2020.103433

Shehzad, K., Xiaoxing, L., \& Kazouz, H. (2020). COVID-19's disasters are perilous than Global Financial Crisis: A rumor or fact?. Finance Research Letters, 36, 101669.

Slade, C. P., Ribando, S. J., \& Fortner, C. K. (2016). Faculty research following. merger: a job stress and social identity theory perspective. Scientometrics, 107(1), 71- 89

Story, J., Castanheira, F., \& Hartig, S. (2016). Corporate social responsibility and organizational attractiveness: implications for talent management. Social Responsibility Journal, 12(3), 484-505.

Su, W., Peng, M. W., Tan, W., \& Cheung, Y. L. (2016). The signaling effect of corporate social responsibility in emerging economies.Journal of business Ethics, 134(3), 479-491.

Tajfel, H., \& Turner, J. C. (1979).An integrative theory of intergroup conflict. In W. G. Austin \& S. Worchel (Eds.), The social psychology of intergroup relations (pp. 33-47). Monterey, CA: Brooks/Cole.

Taylor, P. (2016). The next America: Boomers, millennials, and the looming generational showdown. Hachette UK.

Waples, C. J., \& Brachle, B. J. (2020). Recruiting millennials: Exploring the impact of CSR involvement and pay signaling on organizational attractiveness. Corporate Social Responsibility and Environmental Management, 27(2), 870-880.

Xie, C., Bagozzi, R. P., \& Meland, K. V. (2015). The impact of reputation and identity congruence on employer brand attractiveness. Marketing Intelligence \& Planning, 33(2), 124-146. 
Youn, H., Lee, K., \& Lee, S. (2018). Effects of corporate social responsibility on employees in the casino industry. Tourism Management, 68, 328-335.

Yi, L. T., Liu, B. B., Li, J., Luo, L., Liu, Q., Geng, D., ... \& Wu, D. (2014). BDNF signaling is necessary for the antidepressant-like effect of naringenin. Progress in Neuro-Psychopharmacology and Biological Psychiatry, 48, 135-141.

Yüksel, M. (2015). Employer Branding and Reputation From A Strategic Human Resource Management Perspective. Communications of the IBIMA, 2015, 1.

Zikmund, W. G., Babin, B. J., Carr, J. C., \& Griffin, M. (2013). Business research methods. Cengage Learning.

\section{Appendix}

The instruments were adopted from literature, as mentioned in Table 8.

Table 8. Measurement items

\begin{tabular}{|c|c|c|}
\hline Construct & Items & Source \\
\hline Organizationa & $\begin{array}{l}\text { I look for an organization that provides Hands-on inter- } \\
\text { departmental experience }\end{array}$ & $\begin{array}{l}\text { (Alnıaçık, } \\
\text { 2014) }\end{array}$ \\
\hline $\begin{array}{l}\text { Attractivenes } \\
\mathrm{s}\end{array}$ & $\begin{array}{l}\text { I look for an organization that gives the feeling of } \\
\text { acceptance and belonging } \\
\text { I look for an organization that provides an attractive } \\
\text { overall remuneration package } \\
\text { I look for an organization that both values and makes } \\
\text { use of Creativity } \\
\text { I look for an organization that provides recognition and } \\
\text { appreciation from management } \\
\text { I look for an organization that produces high-quality } \\
\text { products and services }\end{array}$ & \\
\hline $\begin{array}{l}\text { Corporate } \\
\text { Social }\end{array}$ & $\begin{array}{l}\text { I look for an organization that fulfill core responsibilities } \\
\text { towards society }\end{array}$ & $\begin{array}{l}\text { (Klimkiewic } \\
\text { z and }\end{array}$ \\
\hline & $\begin{array}{l}\text { I look for an organization that integrates social and } \\
\text { economic goals }\end{array}$ & $\begin{array}{l}\text { Oltra, } \\
2017)\end{array}$ \\
\hline & $\begin{array}{l}\text { I look for an organization that practices fairness towards } \\
\text { society } \\
\text { I look for an organization that complaisance with law } \\
\text { I look for an organization that shows respect for the } \\
\text { environment } \\
\text { I look fan or organization that practices reliable } \\
\text { communication } \\
\text { I look for an organization that practices a horizon of } \\
\text { profit-making }\end{array}$ & \\
\hline & $\begin{array}{l}\text { I look for organizations that provide a physically } \\
\text { pleasant workplace }\end{array}$ & $\begin{array}{l}\text { (Yi et al., } \\
\text { 2013) }\end{array}$ \\
\hline
\end{tabular}


INTERNATIONAL JOURNAL OF ACADEMIC RESEARCH ECONOMICS AND MANAGEMENT SCIENCES Vol. 10 , No. 3, 2020, E-ISSN: 2226-3624 ㄷ 2020 HRMARS

\begin{tabular}{|c|c|c|}
\hline $\begin{array}{l}\text { Perceived } \\
\text { Work }\end{array}$ & $\begin{array}{l}\text { I look for an organization that is free from uncontrolled } \\
\text { noise levels. }\end{array}$ & \\
\hline Environment & $\begin{array}{l}\text { I look for an organization where I can personalize my } \\
\text { workplace. } \\
\text { I can access my workspace after working hours or on } \\
\text { weekends. }\end{array}$ & \\
\hline $\begin{array}{l}\text { Individual } \\
\text { Value }\end{array}$ & $\begin{array}{l}\text { I look for an organization where each person is treated } \\
\text { fairly. } \\
\text { I look for an organization that provides the freedom to } \\
\text { decide what to do. } \\
\text { I look for an organization where I can do the work that I } \\
\text { enjoy. } \\
\text { I look for an organization that would provide me with } \\
\text { job security. } \\
\text { I look for an organization that provides a wide variety of } \\
\text { different things to do } \\
\text { I look for an organization that considers the balance } \\
\text { between private life and work } \\
\text { I look for an organization where I can demonstrate my } \\
\text { abilities } \\
\text { I look fan or organization that profitability-enhancing } \\
\text { experience }\end{array}$ & $\begin{array}{l}\text { (Catano \& } \\
\text { Morrow, } \\
\text { 2016) }\end{array}$ \\
\hline Organizationa & I look for organizations that are trustable & (Alniacika, \\
\hline I Reputation & $\begin{array}{l}\text { I look for organizations that are credible } \\
\text { I look for organizations that are reputable } \\
\text { I seek organizations that are prestigious }\end{array}$ & 2011) \\
\hline
\end{tabular}

